\title{
Corporate social responsibility in European countries: The keystones of the concept and intercultural connotations
}

\author{
Anna Remišová, Anna Lašáková, Renata Krzykała-Schaefer ${ }^{*}$
}

The article presents research results concerning CSR-related criteria of managerial decision-making and their level of importance from the perspective of students of technically and business oriented study programs across seven European countries. The first part of the article deals with selected influential theoretical and methodological considerations in regard to CSR. The application part focuses firstly on a brief international comparison of results, and secondly on the specification of keystones of the CSR concept, which followed from an exploratory factor analysis. Moreover, cultural dimensions significantly associated with the CSR-related criteria in managerial decisionmaking are being identified.

Der Artikel präsentiert Forschungsergebnisse über die CSR-Kriterien von Management-Entscheidungen und den Grad ihrer Bedeutung aus der Perspektive der Studierenden technischer und wirtschaftlich orientierter Studiengänge in sieben europäischen Ländern. Der erste Teil des Artikels beschäftigt sich mit ausgewählten theoretischen und methodischen Überlegungen in Bezug auf CSR. Der Anwendungsteil konzentriert sich zunächst auf einem kurzen internationalen Vergleich der Ergebnisse und zum anderen auf die Spezifikation der Grundpfeiler des CSR-Konzepts, die aus einer Faktoranalyse hervorgegangen sind. Außerdem werden kulturelle Dimensionen identifiziert, die signifikant mit den CSR-Kriterien in ManagementEntscheidungen verbunden sind.

Key words: GLOBE, CEE countries, students, intercultural differences, corporate social responsibility, managerial decision making (JEL: J24, M14)

\footnotetext{
* Anna Remišová, Professor of Philosophy, Faculty of Management, Comenius University in Bratislava, Slovakia. Main research interests: Business ethics, managerial ethics, corporate code of ethics, forms of institutionalisation of business ethics, and metaethics. Corresponding Address: anna.remisova@fm.uniba.sk Anna Lašáková, Ph.D., Lecturer, Faculty of Management, Comenius University in Bratislava, Slovakia. Main research interests: Cross-cultural management, leadership and business ethics, especially intercultural differences in ethical leadership, in negotiations, and in CSR-related managerial decision-making. Corresponding Address: anna.lasakova@fm.uniba.sk

Renata Krzykała-Schaefer, Ph.D., Lecturer, Faculty of Management, Poznań School of Banking, Poland. Main research interests: Cross-cultural management, effective global management, development of intercultural skills and competencies of managers in the areas of communication, negotiations and effective (ethical) leadership. Corresponding address: renata.schaefer@wsb.poznan.pl
} 


\section{Introduction}

The purpose of our study is to gain a better understanding of the CSR-related decisional criteria from the perspective of students who will, at least to a certain extent, form the next managerial generation in seven European countries (for further information on the GLOBE Student project see the article by Čater, Lang and Szabo in this special issue).

In the first part of our article, basic theoretical and methodological issues are outlined. We assume that it is reasonable to discuss, at least briefly, the conception of CSR, which we consider as a basis for our research. Due to the lack of clarity in academic discussions, it seems that everybody could be an expert on the CSR topic today. Hence, in the introductory part of this article we aim at exploring the basic theoretical issues of the CSR debate. Firstly, we stress that the CSR concept is bound to three basic responsibility-related standards, these being the economic, legal, and ethical criteria of corporate conduct. Secondly, distinctions between the US and European approach to CSR are summarized in order to settle theoretic fallacy in the CSR-related debate. Although some acknowledged authors have already specified these distinctions, many researchers nowadays still fail to reflect on these disparities. From a methodological point of view, differences between the US and European conceptualisations of CSR have always to be taken into account, especially in case somebody interprets data from an international or intercultural research in CSR. The third theoretical stand we want to express regards the notion of values and eligible ways of their measurement. This last theoretical consideration is a necessity since the GLOBE Student research project, which we build upon in this article, derives from the international GLOBE project. Both projects use the same questionnaire. American authors, whose article on CSR in the GLOBE research was published in 2006 (see Waldman et al. 2006) used the term "CSR values of managers". We argue that this term is not applicable due to the methods by which the subject of CSR is researched in the GLOBE Student project. According to our understanding, the design of questionnaire items regarding the CSR concept does not consider the level of importance of CSRrelated values of managers, but the level of importance of selected criteria related to CSR within the process of managerial decision-making.

The primary aim of this article is to examine the overall profile of CSR-related criteria in managerial decision-making from the viewpoint of students from the respective seven countries. This article aspires for investigation of the preferences of an "average" student in our sample in regard to CSR-related criteria. To add some more precision to the findings, a factor analysis delivers information about some interesting patterns in the area of importance of the studied CSR-related criteria. Furthermore, because cultural variables are assumed to have an impact on values and preferences of people, we draw some 
interesting results also with respect to the links between culture and CSR-related criteria.

In summary, our conclusions regard:

- The profile of preferred CSR-related criteria in managerial decisionmaking in the seven participating countries together with a brief international comparison of results.

- Underlying variables regarding the CSR-related criteria are elicited; those being the dimensions of CSR, and subsequently their relative level of importance from the perspective of respondents as well as correlations between those dimensions are calculated.

- Further, in order to add some "fine-grained" knowledge about the interconnection between culture and CSR-related decisional criteria, the statistically significant correlations concerning nine cultural dimensions and the CSR-related criteria are outlined, too.

\section{Theoretical and methodological considerations}

This chapter focuses solely on theoretical and methodological aspects, which we applied in addition to the general theoretical and methodological basis of the whole GLOBE Student project. ${ }^{13}$

The CSR-related criteria of managerial decision-making were assessed in the GLOBE Student questionnaire through seventeen distinct criteria, these being:

- cost control,

- customer satisfaction,

- employees' relations issues such as employees' well-being, safety, and working conditions,

- contribution to the economic welfare of the nation,

- the welfare of the local community,

- employees’ professional growth and development,

- pleasing, respecting, not offending a divine being, a god or an idol for example,

- effects of managerial decisions on the environment,

- ethical considerations,

- effect of managerial decisions on the long-term competitive ability of the company,

13 As for methodological issues and sample structure we refer to the article by Čater, Lang and Szabo in this special issue of JEEMS as well as the Annex of the special issue. 
- effect of managerial decisions on the relationship with other organisations, with which the company does serious business,

- effect of managerial decisions on firm profitability,

- effect of managerial decisions on minority employees,

- effect of managerial decisions on female employees,

- effect of supernatural forces such as auspicious days, forecasts by fortunetellers, and the like,

- effect of managerial decisions on product quality, and finally,

- effect of managerial decisions on the sales volume.

Fifteen of the above mentioned criteria belonged to the CSR concept. The items "pleasing, respecting, not offending a divine being, a god or an idol for example" and "effects of supernatural forces such as auspicious days, forecasts by fortune-tellers, and the like" were added to the questionnaire apart from a common comprehension of CSR, probably to find out whether some transcendental forces and effects would have any impact on decisions from the viewpoint of respondents.

\section{The CSR debate}

Examination of the current CSR discourse provides clear evidence that among researchers there is no unity in the understanding of the CSR concept. For example, the works of Dahlsrut (2006) and Garriga/Melé (2004) indicate a great diversity of CSR definitions, which can be found in contemporary literature. Although for more than sixty years the discussions and researches on CSR have been developed in the academia, no unified definition or model has been outlined. For our article two basic aspects of the CSR debate are vital, namely the stakeholder approach and the differentiation between various types of corporate responsibility.

Stakeholder approach. CSR theory became closely related to stakeholder theory (Crane/Matten 2004; Melé 2008; Ben/Bolton 2011) especially in the 1980s and 1990s. The central idea is that every organisation has to accomplish obligations toward certain groups. As a stakeholder we can count every group which is influenced by the organisation or, on the other hand, which affects in any way the functioning of an organisation. Under the obligations of stakeholders, Freeman (1984) understood stakes or interests which people hold against an organisation. The organisation has to treat all interests in a responsible way. Besides the shareholders, every business organisation has other stakeholder groups that have to be considered conscientiously, for example employees, business partners, customers, competitors, the wider society, local community, government, political parties, media, trade associations, etc. In recent discussions CSR theory continues to be closely interconnected with the 
stakeholder approach. As Buysee and Verbeke (2003) suppose, if the management wants to implement CSR standards in practice, stakeholder management principles have to be involved in the corporate strategy.

Various types of corporate responsibility. Stakeholder theory offers a solid basis for discussions on the CSR topic, both on the theoretical and practical level. It indicates that the organisation has to bear responsibility toward all the stakeholders. The next step would be the precision of the types, or levels of responsibility which can be assumed in a corporation. An excellent example of such an analysis is represented by the four dimensional pyramid model of CSR (Carroll 1979, 1991), which is probably the most influential model nowadays. It is a four-dimensional construct, encompassing the economic, legal, ethical and philanthropic responsibility of an organisation (Carroll 1991). According to Carroll (1991), the economic, legal and ethical levels of CSR are required or expected by society. On the other hand, the philanthropic responsibility includes those business activities which are "just" hoped for in the society where business organisations develop activities. The philanthropic level points to the fact that businesses should behave as corporate citizens within society (Carroll 1991: 229) and reinvest a certain percentage of the profit in activities which promote the quality of life of certain handicapped groups.

At this point it should be mentioned that the questions in the GLOBE Student questionnaire mostly regarded the economic and ethical type of responsibility, completely omitting the legal responsibility of a company. On the other hand, also the stakeholder concept was considered just partially, leaving out some of the stakeholder groups, like labour parties, non-governmental organisations, political parties, media, or creditors.

\section{Differences between the US and European approach to CSR}

The second aspect of CSR discussions, which is often omitted by academics and practitioners, is that there are substantial dissimilarities between the US and European approach to CSR. However, many researchers do not take this discrepancy into account. An example of researching country-related differences regarding CSR was displayed by Maignan and Ralston (2002). In their article, findings from research in four countries - France, the Netherlands, the UK and the US - were discussed, assuming that there are indeed differences in exhibiting eagerness to appear as socially responsible as well as in the employment of varied means to convey social responsibility images in public via web sites. However, these differences were not framed on a theoretical level.

The differences between the US and European conception of CSR were clearly pointed out by Matten and Moon (2008), Búciová (2009), and Remišová and Búciová (2012). The economic responsibility dimension in the European approach does not have the most important position as it has in the US approach to CSR. In a European context, the economic, legal and ethical dimensions are 
equally important for a responsible performance of an organisation. Furthermore, according to Matten and Moon (2008), the economic responsibility in European countries is defined in a broader way than in the US approach, not only including the shareholders, but also other stakeholders like employees, business partners, or customers. Due to differing legal systems, responsibility toward employees reflected in the form of employee benefits, which are legally bond in many European countries, is defined as a part of the ethical responsibility in the US approach to CSR. Moreover, in the US approach to CSR the philanthropic level of responsibility occupies a substantially different position than it does in Europe. The US approach to philanthropy is built on the idea that a corporation has the commitment to invest a percentage of its profit back to society in a form of philanthropic activities. On the other hand, many European countries have to deal with high taxation in regard to the corporate sector. Although in European countries the financial donations oriented toward the local communities or people in need are common, these philanthropicallyoriented activities are not regarded as an important part of CSR corporate activities. The essential character of CSR from the European perspective lies in the adherence to ethical responsibility toward all stakeholders of a corporation (see Remišová/Búciová 2012: 275).

The authors of this article presume that it is important to differentiate between the two concepts, because of societal, cultural, legal and economic distinctions between European countries and the US. To be able to successfully implement CSR into the daily operations of business organisations, its working principles, values, and norms have to be aligned with macro-economic aspects of the external business environment. The cultural, legal or broader societal structures in the US and European countries as well as among European countries as such, differ substantially.

At this point it should be stressed that the design of the CSR items in the GLOBE Student questionnaire was derived from the US approach to the CSR concept, blending two theoretical approaches, the CSR and the stakeholder approach, but not fully covering any of the two. As outlined earlier, perhaps due to the US approach to the CSR research, the legal type of corporate responsibility was omitted from the questionnaire. Moreover, the economic responsibility was stressed more than any other type of corporate responsibility, addressing five explicitly economic items and just one explicitly ethical item in the questionnaire. This was an important methodological issue, which had an impact on the interpretation of our results in the discussion section.

\section{On the character of the CSR-related questionnaire items in the GLOBE Student research}

Our article follows in a certain way the study by Waldman, D. A., Sully de Luque, M., Washburn, N., House, R. J. and colleagues from 2006 (Waldman et 
al. study in the following). It was published in the Journal of International Business Studies and deals with the cultural and leadership predictors of what the authors labelled as "CSR-related values" of top management.

The authors of this article assume that, according to the questionnaire content, the GLOBE Student CSR-related study was not aimed at studying neither "corporate social values" nor the "personal values of respondents". The questionnaire items reflected the level of importance of CSR-related criteria in decision-making from the viewpoint of respondents, who, in our case, were students of engineering and business study programs. Respondents were asked to indicate on a 7-point scale, how much importance should be assigned to each of the factors listed below when making critical management decisions. "One" meant that the criterion should have a zero importance, and that this criterion does not have any importance at all, and "seven" meant that this criterion should have the greatest importance, being more important than all other factors, which may play a role in the key managerial decision-making process. Thus, it has to be pointed out that the questionnaire did not deal with "corporate social values" but "CSR-related criteria".

As Schwartz noted (Schwartz 1994; Schwartz et al. 2001; Schwartz 2007), values can be apprehended as beliefs bound to emotions of people and as such have motivational power, representing desired goals which people want to attain. Hence, they serve as a criterion for decision-making. However, the diction of the questionnaire in the GLOBE Student research related to the level of importance, which should be assigned to seventeen criteria related to CSR in general. Our interpretation of the research results in the discussion part of the article takes into account this particular assignment for respondents written in the questionnaire, and we assume that it plausibly delineates the studied phenomena as the CSR-related decisional criteria rather than the CSR-related values.

\section{Data processing}

After assembling the completed questionnaires, all data were transcribed into an excel-type file and consecutively processed in the SPSS program. We performed a number of different statistical analysis methods in order to gain answers to our research questions, like the test of normal distribution, descriptive statistics, exploratory factor analysis and correlation analysis of the data. The next part of this article focuses first on a brief description of the results in regard to the level of importance of CSR-related criteria for the whole sample as well as for each of the respective countries. Subsequently, results of the in-depth analysis of the links between the cultural variables and the CSR-related issues are described. 


\section{Research results}

Overall profile of CSR-related criteria in managerial decision-making in the seven studied countries

Looking at the joint sample with respect to the importance of CSR-related criteria, the observation can be made that students have a clear vision of which important factors should be taken into account in critical managerial decisions. Table 1 shows the importance of CSR-related criteria in the joint sample of seven investigated countries (as a cluster).

Table 1: CSR-related criteria and their importance in the decision making process in the joint sample (mean values)

\begin{tabular}{|l|c|c|c|}
\hline CSR-Related Decisional Criteria & Mean & Rank & Std. dev. \\
\hline Cost control & 5.25 & 9 & 1.07 \\
\hline Customer satisfaction & 6.01 & 1 & 1.03 \\
\hline $\begin{array}{l}\text { Employees' relations issues such as employees' } \\
\text { well-being, safety, working conditions }\end{array}$ & 5.53 & 5 & 1.07 \\
\hline Contribution to the economic welfare of the nation & 4.43 & 13 & 1.34 \\
\hline The welfare of the local community & 4.71 & 12 & 1.31 \\
\hline Employees' professional growth and development & 5.29 & 8 & 1.05 \\
\hline $\begin{array}{l}\text { Pleasing, respecting, not offending a divine being- } \\
\text { a god or an idol for example }\end{array}$ & 3.55 & 16 & 1.82 \\
\hline Effects on the environment & 5.13 & 10 & 1.30 \\
\hline Ethical considerations & 4.77 & 11 & 1.37 \\
\hline $\begin{array}{l}\text { Effect on the long-term competitive ability of the } \\
\text { organisation }\end{array}$ & 5.56 & 4 & 1.10 \\
\hline $\begin{array}{l}\text { Effect on relationship with other organisations with } \\
\text { which you do serious business (business partners) }\end{array}$ & 5.38 & 7 & 0.98 \\
\hline Effect on firm profitability & 5.62 & 3 & 1.11 \\
\hline Effect on minority employees & 4.23 & 15 & 1.40 \\
\hline Effect on female employees & 4.35 & 14 & 1.43 \\
\hline $\begin{array}{l}\text { Effect of supernatural forces such as auspicious } \\
\text { days, forecasts by fortune-tellers, and the like }\end{array}$ & 1.84 & 17 & 1.25 \\
\hline Effect on product quality & 5.79 & 2 & 1.03 \\
\hline Effect on sales volume & 5.44 & 6 & 1.09 \\
\hline
\end{tabular}


Notes: Answers on the 7-point scale with $1=$ this factor is of no importance, and $7=$ this factor should be considered more important than all other considerations. The items are arranged according to the original ordering in the questionnaire.

It turned out that the "average" student in the sample would give preference to customer satisfaction (6.01), product quality (5.79) followed by firm profitability (5.62) and long-term competitiveness (5.56). Rather high importance is given to employees' well-being (5.53), sales volume (5.44) and relations to important business partners (5.38) followed by employees' development (5.29), cost control (5.25) and effects on the environment (5.13).

Less importance is given to ethical considerations (4.77), contributions to local community welfare (4.71) and economic welfare of the nation (4.43), followed by the special issue of female employees (4.35) or minorities (4.23). Only very limited attention is attached to pleasing, respecting or not offending gods (3.55) or beliefs in supernatural forces (1.84).

Relying on some national results, the following preferences are displayed pinpointing only to the extremes within our sample, i.e. results with the highest or the lowest means:

- Slovenia expresses the highest preference within the group for ethical considerations (5.18) but, on the other hand, students in Slovenia were the most sceptical fraction within our sample in terms of the importance of eight other CSR-related factors like cost control (4.82), customer satisfaction (5.5), employees' well-being (5.26), firm profitability (4.89), minority employees (3.82), female employees (4.00), product quality (5.47) and sales volume (4.85).

- Germany scores highest within the group on cost control (5.63), long-term competitiveness (5.93), quality of products (6.01), sales volume (5.79), and relationship to business partners (5.67). At the same time, students in Germany express the weakest preference within the group for respecting a divine being (2.20) and the effect of supernatural forces (1.42).

- Romania scores highest among the examined countries on customer satisfaction (6.18), national welfare (4.69), local community welfare (4.86), effects on the environment (5.37) and, at the same time, expresses the weakest preference for long-term competitiveness (5.10) and business partners relations (5.05).

- Poland scores highest among the seven investigated countries in terms of employees' well-being (5.70), employees' development (5.45), respecting a divine being (4.63), minority employees (4.53) and the effect of supernatural forces (2.24).

- The Czech Republic scores highest of the whole sample with reference to firm profitability (5.92), and the lowest in the effects on the environment (4.50), 
national welfare (4.00), local community welfare (4.26), and employees' development (4.96).

- Austria scores the highest in the effects with regard to female employees (4.66).

- Finally, the Slovak sample was positioned within the overall sample with neither lowest nor highest mean values of the studied seventeen CSRrelated criteria.

It is interesting that, when we look at the list of the first five most important CSR-related criteria in each country, despite all these differences, we can observe a lot of similarities (see Table 2). 


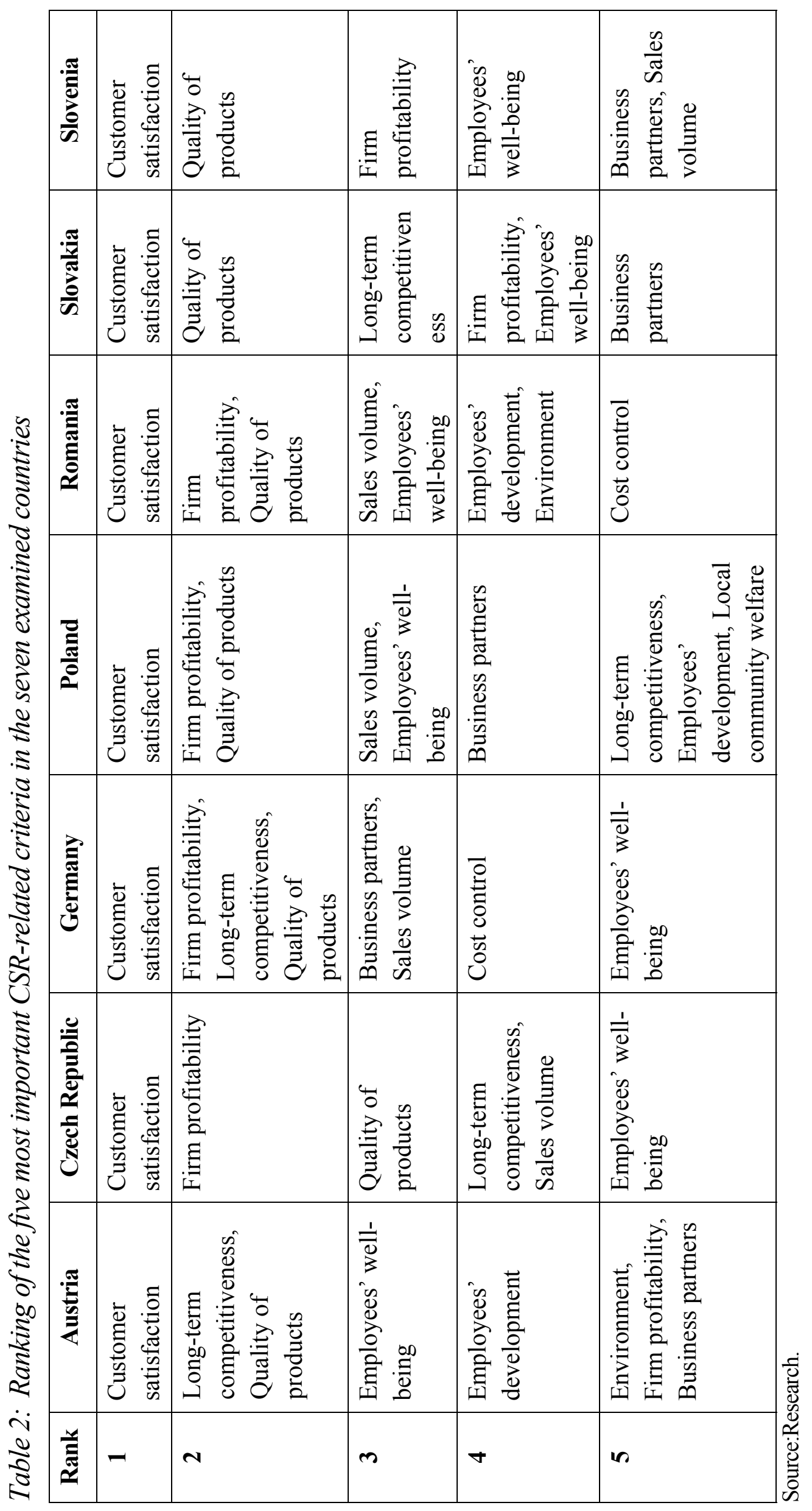


Research definitely confirmed that in all seven countries customer satisfaction ranked highest in the hierarchy of importance among all CSR-related criteria. Product quality and profitability are also highly valued in all examined countries and reach either second or third rank in the hierarchy of importance. Long-term competitiveness, on the other hand, is valued highly ( ${ }^{\text {nd }}$ position) in Austria and Germany, reaches the $3^{\text {rd }}$ place in Slovakia, the $4^{\text {th }}$ in the Czech Republic, the $5^{\text {th }}$ in Poland and is not in the top 5 in Slovenia. Employees' well-being is also on the ranking list but with differing importance. In the case of Austria, Poland and Romania, it is on the $3^{\text {rd }}$ place, in the Slovak Republic and in Slovenia on the $4^{\text {th }}$ position and in the case of the Czech Republic it comes $5^{\text {th }}$. Both sales volume and relations with business partners are present in nearly all the examined countries but, as in the previous case, with different importance. For example, Germany places business partners' relations on the $3^{\text {rd }}$ position, Poland on the $4^{\text {th }}$ and Austria, the Slovak Republic and Slovenia on the $5^{\text {th }}$. In the case of the Czech Republic, it is outside the list of the five most important CSR-related criteria. It is also worth mentioning that some criteria found their way to the list only in the case of one or two countries. For example, local community welfare is only present in Poland, cost control in Germany and Romania, effects on the environment in Austria and Romania, and employees' development is mentioned only with regard to Austria, Poland and Romania.

\section{Revealing the keystones of the CSR concept: Latent dimensions of CSR-related criteria in managerial decision-making}

An exploratory factor analysis was performed in order to identify latent variables in respect to the studied decisional criteria. For the extraction method Maximum Likelihood was indicated, together with the rotation method Oblimin with Kaiser Normalisation. The item "Pleasing, respecting, not offending a divine being" was excluded from the analysis, because other factors had an undefined impact on this item. Table 3 indicates that according to the levels of variance the four-factor result is the optimal solution. 
Table 3: Total variance explained

\begin{tabular}{|c|c|c|c|c|c|c|c|}
\hline & $\begin{array}{l}\text { Initial } \\
\text { Eigen- } \\
\text { values }\end{array}$ & & & $\begin{array}{l}\text { Extrac- } \\
\text { tion Sums } \\
\text { of Squared } \\
\text { Loadings }\end{array}$ & & & $\begin{array}{l}\text { Rotation } \\
\text { Sums of } \\
\text { Squared } \\
\text { Loadings }\end{array}$ \\
\hline Factor & Total & $\begin{array}{l}\% \text { of } \\
\text { Variance }\end{array}$ & $\begin{array}{l}\text { Cumula- } \\
\text { tive \% }\end{array}$ & Total & $\begin{array}{l}\% \text { of } \\
\text { Variance }\end{array}$ & $\begin{array}{l}\text { Cumula- } \\
\text { tive \% }\end{array}$ & Total \\
\hline 1 & 4.299 & 26.866 & 26.866 & 3.682 & 23.015 & 23.015 & 2.377 \\
\hline 2 & 2.455 & 15.346 & 42.212 & 2.006 & 12.538 & 35.553 & 2.209 \\
\hline 3 & 1.253 & 7.829 & 50.041 & 0.819 & 5.117 & 40.670 & 2.368 \\
\hline 4 & 1.061 & 6.632 & 56.673 & 0.598 & 3.737 & 44.407 & 2.706 \\
\hline$\ldots$. & & & & & & & \\
\hline 16 & 0.345 & 2.157 & 100.000 & & & & \\
\hline
\end{tabular}

Source: Research.

Our results show that four latent variables were discovered. We labelled them “Common Good”, "Profit”, "Ethics” and "Longitudinality” (see Table 4).

Table 4: The structure matrix

\begin{tabular}{|l|l|l|l|l|}
\hline & $\begin{array}{l}\text { Factor 1 } \\
\text { Common } \\
\text { Good }\end{array}$ & $\begin{array}{l}\text { Factor 2 } \\
\text { Profit }\end{array}$ & $\begin{array}{l}\text { Factor 3 } \\
\text { Ethics }\end{array}$ & $\begin{array}{l}\text { Factor 4 } \\
\text { Longitu- } \\
\text { dinality }\end{array}$ \\
\hline Cost control & 0.050 & 0.506 & 0.088 & 0.409 \\
\hline Customer satisfaction & 0.223 & 0.388 & 0.167 & 0.677 \\
\hline $\begin{array}{l}\text { Employees' relations issues } \\
\text { such as employees' well- } \\
\text { being, safety, working } \\
\text { conditions }\end{array}$ & 0.453 & 0.158 & 0.445 & 0.470 \\
\hline $\begin{array}{l}\text { Contribution to the economic } \\
\text { welfare of the nation }\end{array}$ & 0.802 & -0.031 & 0.364 & 0.135 \\
\hline $\begin{array}{l}\text { The welfare of the local } \\
\text { community }\end{array}$ & 0.798 & -0.003 & 0.389 & 0.213 \\
\hline $\begin{array}{l}\text { Employees' professional } \\
\text { growth and development }\end{array}$ & 0.448 & 0.201 & 0.370 & 0.516 \\
\hline Effects on the environment & 0.401 & -0.010 & 0.337 & 0.400 \\
\hline
\end{tabular}




\begin{tabular}{|l|l|l|l|l|}
\hline Ethical considerations & 0.403 & -0.072 & 0.511 & 0.299 \\
\hline $\begin{array}{l}\text { Effect on the long-term } \\
\text { competitive ability of the } \\
\text { organisation }\end{array}$ & 0.101 & 0.435 & 0.133 & 0.596 \\
\hline $\begin{array}{l}\text { Effect on relationship with } \\
\text { other organisations with } \\
\text { which you do serious } \\
\text { business, for example } \\
\text { suppliers, government } \\
\text { agencies, partners in strategic } \\
\text { alliances }\end{array}$ & 0.131 & 0.374 & 0.184 & 0.390 \\
\hline Effect on firm profitability & 0.002 & 0.766 & 0.080 & 0.332 \\
\hline Effect on minority employees & 0.396 & 0.072 & 0.804 & 0.122 \\
\hline Effect on female employees & 0.313 & 0.085 & 0.764 & 0.115 \\
\hline Effect on product quality & 0.148 & 0.470 & 0.168 & 0.656 \\
\hline Effect on sales volume & 0.040 & 0.744 & 0.090 & 0.351 \\
\hline $\begin{array}{l}\text { Effect of supernatural forces } \\
\text { such as auspicious days, } \\
\text { forecasts by fortune tellers, } \\
\text { and the like }\end{array}$ & 0.102 & -0.170 & 0.114 & -0.286 \\
\hline $\begin{array}{l}\text { Extraction Method: Maximum Likelihood. } \\
\text { Rotation Method: Oblimin with Kaiser Normalisation. }\end{array}$ & & & & \\
\hline
\end{tabular}

Source: Research.

It is worth mentioning that our results confirm two levels in Carroll's so-called pyramid model of CSR (Carroll 1991, see the theoretical considerations in the first part of this article). Factor Profit and factor Ethics point to two levels of Carroll's model, namely the economic and ethical responsibility of a company. Furthermore our findings from the factor analysis specify two important aspects of CSR, which are the longitudinally-oriented characteristics of CSR and the orientation of the CSR concept toward the principle of common good.

After assessing the inner composition of the four factors, we performed a correlation analysis of the respective four factors as well as the descriptive statistical analysis in order to gain a better understanding of the relations between the factors and their level of importance in managerial decision-making (Table 5). 
Table 5: Four-factor correlation matrix

\begin{tabular}{|l|l|l|l|l|}
\hline & $\begin{array}{l}\text { Factor } \\
\text { Profit }\end{array}$ & $\begin{array}{l}\text { Factor } \\
\text { Common } \\
\text { Good }\end{array}$ & $\begin{array}{l}\text { Factor } \\
\text { Ethics }\end{array}$ & $\begin{array}{l}\text { Factor } \\
\text { Longitudinality }\end{array}$ \\
\hline Factor Profit & & $0.062^{*}$ & $0.098^{* *}$ & $0.468 * *$ \\
\hline $\begin{array}{l}\text { Factor Common } \\
\text { Good }\end{array}$ & $0.062 *$ & & $0.437 * *$ & $0.424 * *$ \\
\hline Factor Ethics & $0.098^{* *}$ & $\mathbf{0 . 4 3 7 * *}$ & & $0.379 * *$ \\
\hline $\begin{array}{l}\text { Factor } \\
\text { Longitudinality }\end{array}$ & $\mathbf{0 . 4 6 8 * *}$ & $\mathbf{0 . 4 2 4 * *}$ & $\mathbf{0 . 3 7 9 * *}$ & \\
\hline
\end{tabular}

Source: Research. Notes: ${ }^{* *}$ Correlation is significant at the 0.01 level (2-tailed); ${ }^{*}$ Correlation is significant at the 0.05 level (2-tailed).

Table 5 shows the correlations of the four factors, where basic outcomes can be outlined as follows:

- The factor Longitudinality correlates positively and relatively strongly with the factors Profit, Common Good, and Ethics.

- The factor Ethics correlates positively and relatively strongly with Common Good.

- There is a relatively weak connection between Profit and Common Good as well as between Ethics and Profit.

Descriptive statistics were performed for the four factors, too. The results are shown in Table 6.

Table 6: Descriptive statistics for the four factors

\begin{tabular}{|l|l|l|l|l|l|l|l|}
\hline & N & Mean & Rank & $\begin{array}{l}\text { Std. } \\
\text { Deviati } \\
\text { on }\end{array}$ & $\begin{array}{l}\text { Vari- } \\
\text { ance }\end{array}$ & $\begin{array}{l}\text { Skew- } \\
\text { ness }\end{array}$ & $\begin{array}{l}\text { Kurt- } \\
\text { osis }\end{array}$ \\
\hline Factor Profit & 2346 & 5.44 & 1 & 0.87 & 0.76 & -0.91 & 1.44 \\
\hline $\begin{array}{l}\text { Factor } \\
\text { Common Good }\end{array}$ & 2346 & 4.76 & 3 & 1.03 & 1.06 & -0.38 & 0.15 \\
\hline Factor Ethics & 2344 & 4.45 & 4 & 1.12 & 1.25 & -0.39 & 0.07 \\
\hline $\begin{array}{l}\text { Factor } \\
\text { Longitudinality }\end{array}$ & 2346 & 5.06 & 2 & 0.59 & 0.35 & -0.83 & 1.48 \\
\hline
\end{tabular}

Source: Research. Note: Answers on the 7-point scale with $1=$ this factor is of no importance, and $7=$ this factor should be considered more important than all other considerations. 
According to the results of the descriptive analysis, we can conclude that:

- The factor Profit seems to have the highest level of importance in the decision-making process.

- According to the level of importance the factor Longitudinality was ranked second, followed the factor Common Good (third).

- The factor Ethics ranked as the least important one from the students' point of view.

\section{Correlations between cultural preferences and CSR-related criteria in managerial decision-making}

One of the aims of this article was to examine relationships between certain cultural variables and CSR-related criteria. From the GLOBE Student questionnaire we considered the nine cultural value dimensions. From a methodological point they represent, similar to the CSR decisional criteria, desired-end states. In Table 7 correlations between the four factors and cultural preferences are indicated.

Table 7: Correlations between the four CSR-related decisional factors and cultural dimensions

\begin{tabular}{|c|c|c|c|c|c|c|c|c|c|}
\hline & 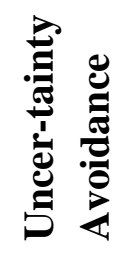 & 莺 & 离 & 总 & 을 & 兰 & 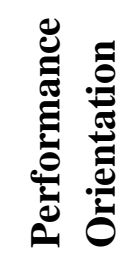 & 兽 & 总 \\
\hline $\begin{array}{l}\text { Factor } \\
\text { Profit }\end{array}$ & $\begin{array}{l}0.210 \\
* *\end{array}$ & $\begin{array}{l}0.164 \\
* *\end{array}$ & $\begin{array}{l}-0.170 \\
* *\end{array}$ & $\begin{array}{l}0.083 \\
* *\end{array}$ & $\begin{array}{l}0.276 \\
* *\end{array}$ & $\begin{array}{l}0.119 \\
* *\end{array}$ & $\begin{array}{l}0.396 \\
* *\end{array}$ & $\begin{array}{l}0.162 \\
* *\end{array}$ & $\begin{array}{l}-0.048 \\
*\end{array}$ \\
\hline $\begin{array}{l}\text { Factor } \\
\text { Common } \\
\text { Good }\end{array}$ & $\begin{array}{l}0.152 \\
* *\end{array}$ & $\begin{array}{l}0.041 \\
*\end{array}$ & $\begin{array}{l}-0.214 \\
* *\end{array}$ & $\begin{array}{l}0.203 \\
* *\end{array}$ & $\begin{array}{l}0.144 \\
* *\end{array}$ & $\begin{array}{l}0.265 \\
* *\end{array}$ & $\begin{array}{l}0.115 \\
* *\end{array}$ & $\begin{array}{l}0.063 \\
*\end{array}$ & $\begin{array}{l}-0.190 \\
* *\end{array}$ \\
\hline $\begin{array}{l}\text { Factor } \\
\text { Ethics }\end{array}$ & $\begin{array}{l}0.078 \\
* *\end{array}$ & 0.022 & $\begin{array}{l}-0.249 \\
* *\end{array}$ & $\begin{array}{l}0.089 \\
* *\end{array}$ & $\begin{array}{l}0159 * \\
*\end{array}$ & $\begin{array}{l}0.250 \\
* *\end{array}$ & $\begin{array}{l}0.087 \\
* *\end{array}$ & $\begin{array}{l}0.132 \\
* *\end{array}$ & $\begin{array}{l}-0.187 \\
* *\end{array}$ \\
\hline $\begin{array}{l}\text { Factor } \\
\text { Longitudi } \\
\text { nality }\end{array}$ & $\begin{array}{l}0.149 \\
* *\end{array}$ & $\begin{array}{l}0.175 \\
* *\end{array}$ & $\begin{array}{l}-0.278 \\
* *\end{array}$ & $\begin{array}{l}0.104 \\
* *\end{array}$ & $\begin{array}{l}0.256 \\
* *\end{array}$ & $\begin{array}{l}0.223 \\
* *\end{array}$ & $\begin{array}{l}0.326 \\
* *\end{array}$ & $\begin{array}{l}0.175 \\
* *\end{array}$ & $\begin{array}{l}-0.160 \\
* *\end{array}$ \\
\hline
\end{tabular}

Source: Research. Notes: ${ }^{* *}$ Correlation is significant at the 0.01 level (2-tailed). ${ }^{*}$ Correlation is significant at the 0.05 level (2-tailed).

Our results clearly indicate that all nine cultural dimensions are statistically significantly correlated with the factors. However, the level of the Pearson coefficient is somehow low. From Table 7 we can conclude as most important findings that: 
- Performance Orientation is positively correlated especially with the Profit and Longitudinality factors, these being the strongest correlations among the four factors in regard to cultural dimensions.

- The Power Distance and Assertiveness dimensions are negatively correlated with all four factors.

- Preference of the Power Distance dimension negatively correlates especially with Longitudinality, Ethics and concern for the Common Good.

- The Uncertainty Avoidance dimension is positively correlated especially with Profit.

- Institutional Collectivism is positively correlated with Common Good (which stands for the societal interests of the nation and local community).

- In-group Collectivism is positively significantly linked to Profit and Longitudinality.

- Preference of Humane Orientation is positively linked especially to Ethics, Common Good and Longitudinality.

- Among other significant correlations the result for the Future Orientation dimension should also be mentioned, which is linked with the strongest correlation to the factors Longitudinality and Profit. Values of Assertiveness are negatively linked especially to Common Good and Ethics, followed by the factor Longitudinality.

In order to gain a more complex picture of the interconnectedness of cultural preferences with the CSR-related decisional criteria, correlations between the 17 CSR criteria and the nine cultural dimensions were calculated. Results show that from the 153 pairs of relations only 13 relations were not significantly correlated. All statistically significant correlations are shown in Table 8. 


\begin{tabular}{|c|c|c|c|c|c|c|c|}
\hline 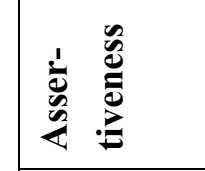 & 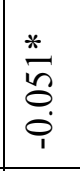 & 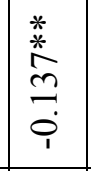 & 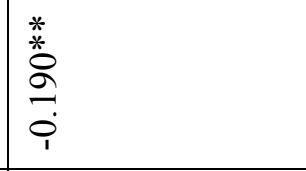 & 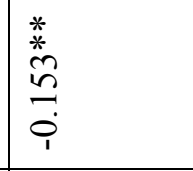 & 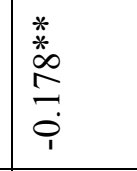 & 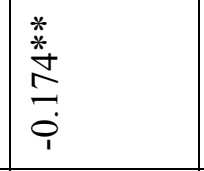 & \\
\hline 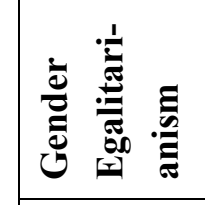 & 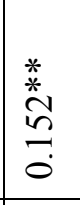 & 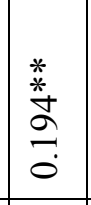 & $\begin{array}{l}. \\
0.0 \\
0 \\
0 \\
0 \\
0\end{array}$ & & & 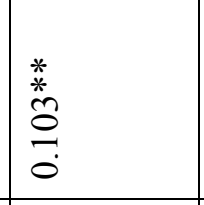 & \begin{tabular}{l}
$*$ \\
\multirow{2}{*}{} \\
iे \\
0 \\
$i$ \\
\end{tabular} \\
\hline 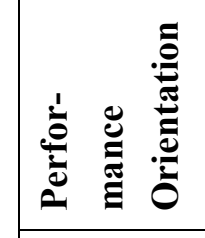 & $\begin{array}{l} \\
\text { :. } \\
\text { : } \\
0 \\
0 \\
0\end{array}$ & 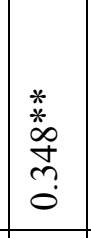 & 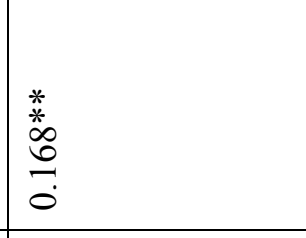 & $\begin{array}{l}* \\
* \\
0 \\
0 \\
0 \\
0 \\
0\end{array}$ & 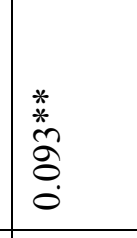 & 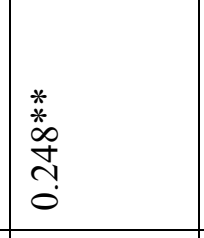 & 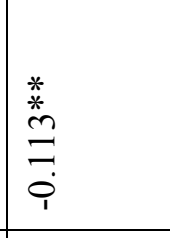 \\
\hline 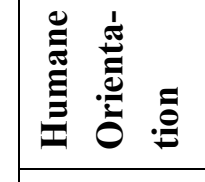 & 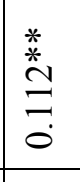 & 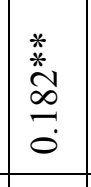 & 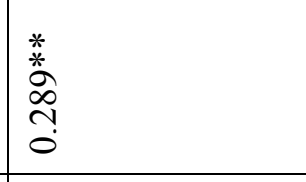 & 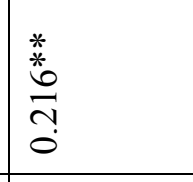 & 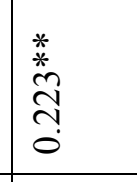 & 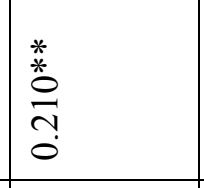 & $\begin{array}{l}\text { *. } \\
i \\
i \\
0 \\
0\end{array}$ \\
\hline 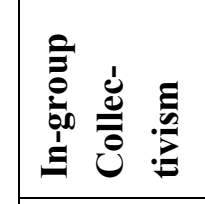 & 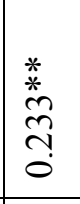 & 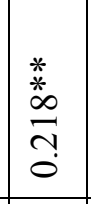 & $\begin{array}{l}\text { : } \\
\text { i. } \\
\text { तु } \\
0\end{array}$ & $\begin{array}{l}* \\
\stackrel{*}{*} \\
\\
0 \\
\end{array}$ & $\begin{array}{l}\text { 蒂 } \\
0 \\
0 \\
0 \\
0\end{array}$ & $\frac{.}{*}$ & \\
\hline 訔总高言咅 & $\begin{array}{l}\text { *. } \\
\text { : } \\
\text { o. } \\
0 \\
0 \\
0\end{array}$ & 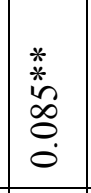 & 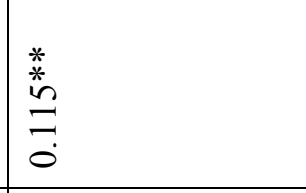 & 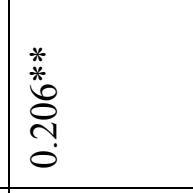 & $\begin{array}{l}* \\
* \\
0 \\
? \\
0 \\
0\end{array}$ & 晜 & \\
\hline 总 & $\begin{array}{l}\frac{*}{3} \\
\stackrel{*}{6} \\
0 \\
\\
\end{array}$ & \begin{tabular}{|l|}
\multirow{*}{*}{} \\
$\hat{w}$ \\
$\hat{n}$ \\
$i$ \\
$i$ \\
\end{tabular} & 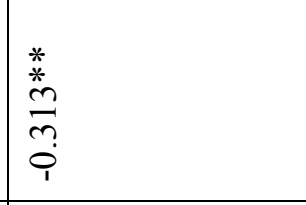 & 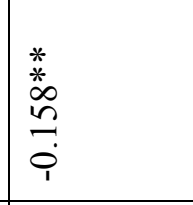 & $\begin{array}{l}* \\
* \\
\stackrel{*}{c} \\
\\
i \\
\end{array}$ & 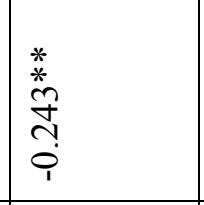 & \\
\hline 童焉 & 啇 & 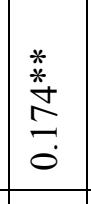 & & & & 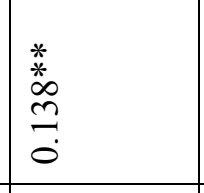 & \\
\hline 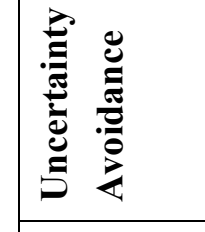 & 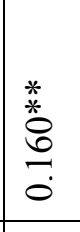 & 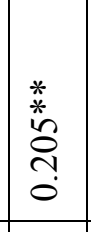 & 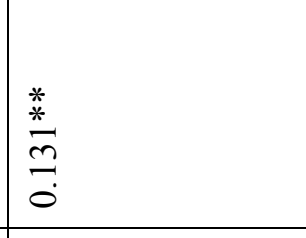 & 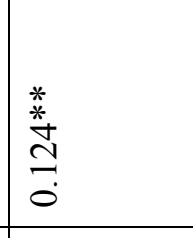 & 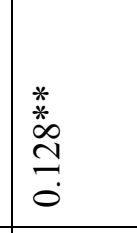 & 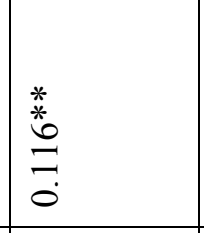 & 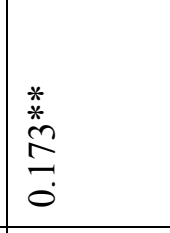 \\
\hline 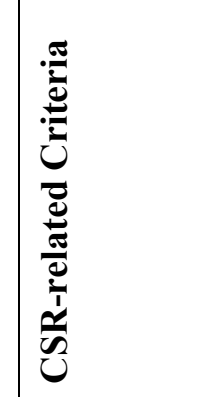 & 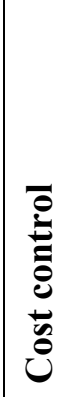 & 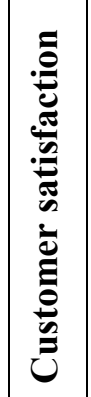 & 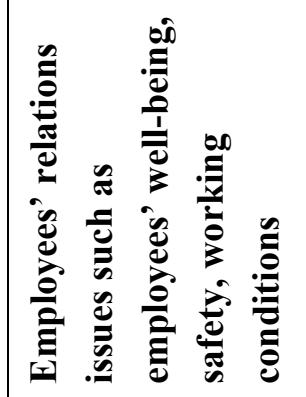 & 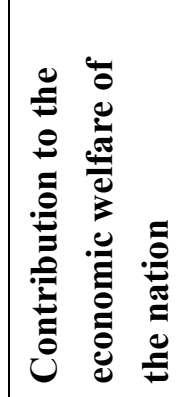 & 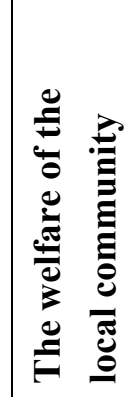 & 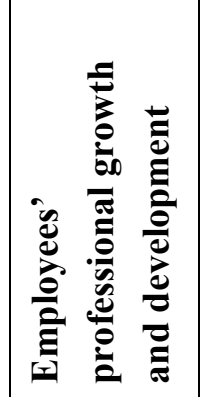 & 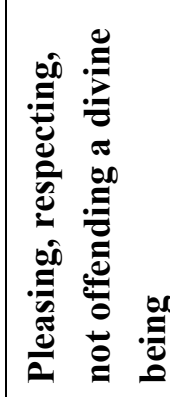 \\
\hline
\end{tabular}




\begin{tabular}{|c|c|c|c|c|c|c|c|c|c|}
\hline 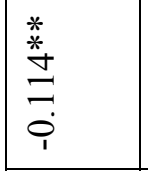 & $\begin{array}{l}\stackrel{*}{*} \\
\stackrel{0}{n} \\
\stackrel{i}{i}\end{array}$ & 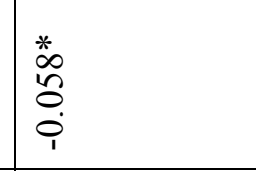 & 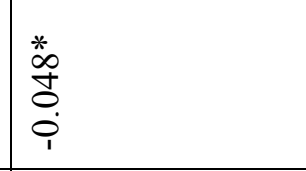 & & 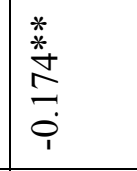 & 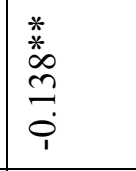 & 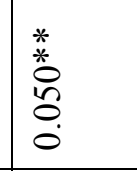 & 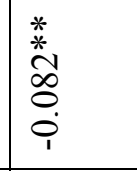 & \\
\hline 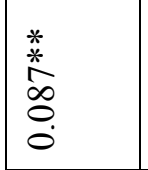 & $\begin{array}{l}\text { *. } \\
\stackrel{*}{0} \\
\stackrel{0}{0}\end{array}$ & 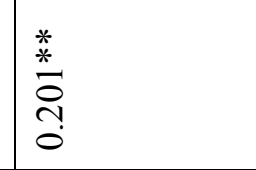 & $\begin{array}{l}\text { 竞 } \\
\stackrel{0}{0} \\
0\end{array}$ & 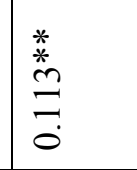 & $\begin{array}{l}\text { 善 } \\
\text { ô } \\
0\end{array}$ & $\begin{array}{l}\stackrel{*}{*} \\
\stackrel{*}{\infty} \\
0\end{array}$ & 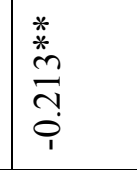 & 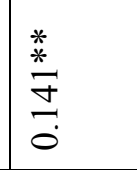 & $\begin{array}{l}\text { 㐘 } \\
\text { dy } \\
0\end{array}$ \\
\hline 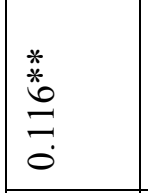 & 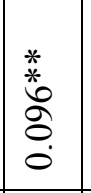 & $\begin{array}{l}\stackrel{*}{*} \\
\stackrel{*}{*} \\
\stackrel{3}{0}\end{array}$ & 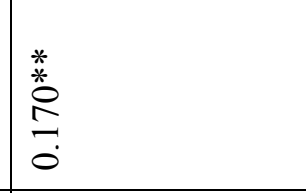 & 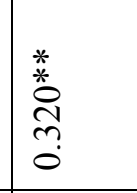 & 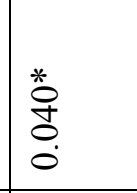 & 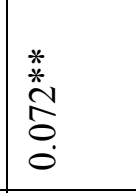 & 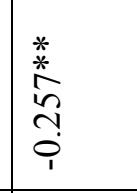 & 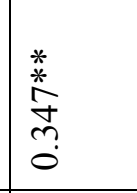 & 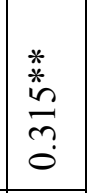 \\
\hline 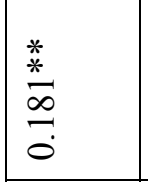 & 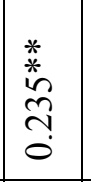 & 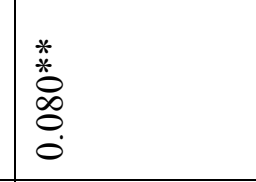 & $\begin{array}{l}\text { 美 } \\
\text { 总 } \\
\text { 号 }\end{array}$ & 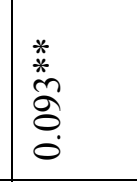 & $\begin{array}{l}\text { : } \\
\stackrel{*}{0} \\
\stackrel{0}{0} \\
0\end{array}$ & 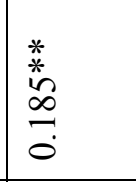 & 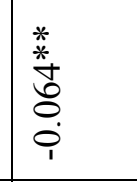 & 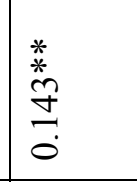 & 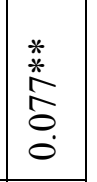 \\
\hline 丵 & $\begin{array}{l}\frac{*}{*} \\
\stackrel{*}{0} \\
\end{array}$ & 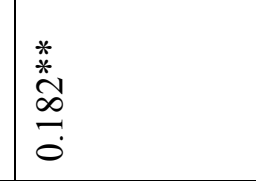 & $\frac{.}{\frac{.}{3}}$ & 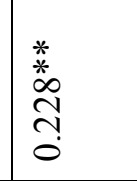 & 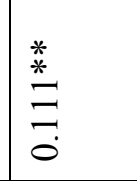 & 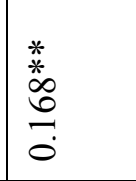 & 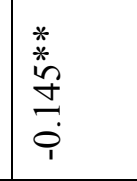 & $\begin{array}{l}\text { *. } \\
\stackrel{*}{0} \\
\stackrel{0}{0}\end{array}$ & 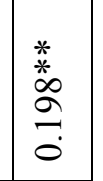 \\
\hline 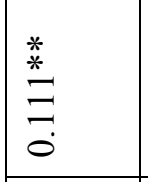 & $\begin{array}{l}\text { : } \\
\text { : } \\
\text { o. } \\
\dot{0}\end{array}$ & 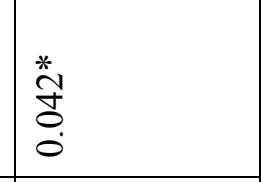 & \begin{tabular}{l}
$*$ \\
\multirow{0}{*}{} \\
0 \\
0
\end{tabular} & $\begin{array}{l}\text { *0. } \\
\text { : } \\
0 \\
0\end{array}$ & $\begin{array}{l}\text { 畨 } \\
\text { 足 } \\
\end{array}$ & $\begin{array}{l}* 0 \\
0 \\
0 \\
0 \\
0\end{array}$ & 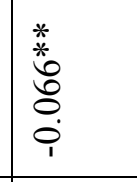 & 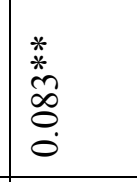 & 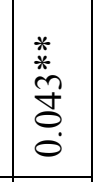 \\
\hline 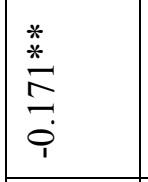 & 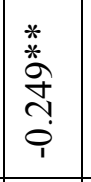 & 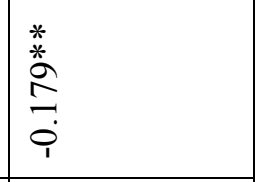 & 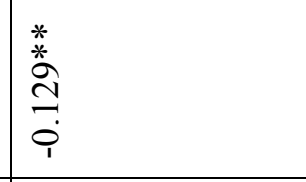 & 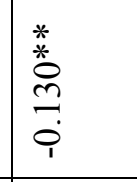 & 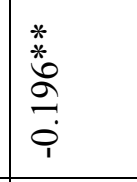 & 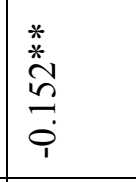 & $\begin{array}{l}\frac{*}{*} \\
\frac{*}{2} \\
0\end{array}$ & 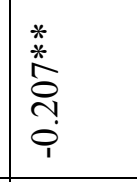 & 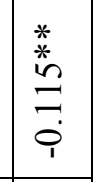 \\
\hline 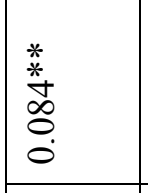 & 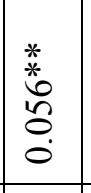 & 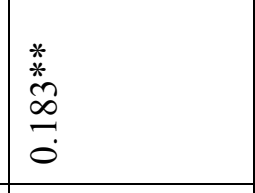 & 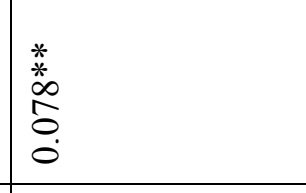 & 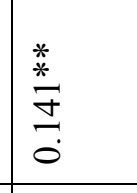 & & & $\begin{array}{l}\text { 菨 } \\
\dot{0} \\
\stackrel{0}{0} \\
\stackrel{i}{i}\end{array}$ & 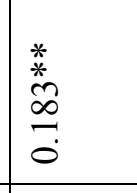 & 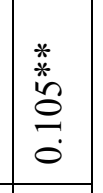 \\
\hline 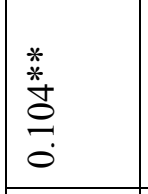 & $\begin{array}{l}\text { 类 } \\
\text { 号 } \\
0\end{array}$ & & 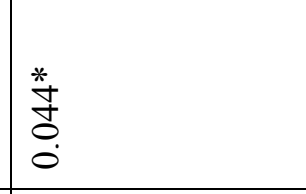 & 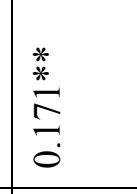 & 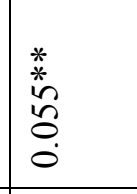 & 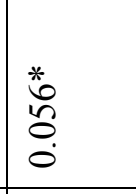 & $\begin{array}{l}\text { 恶 } \\
\stackrel{0}{0} \\
\dot{i}\end{array}$ & $\frac{\frac{*}{4}}{\frac{3}{n}} \frac{1}{0}$ & $\begin{array}{l}\text { * } \\
\text { : } \\
\text { - } \\
0 \\
\end{array}$ \\
\hline 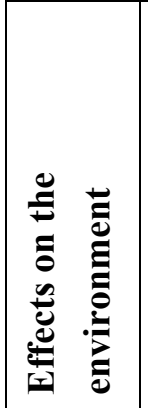 & 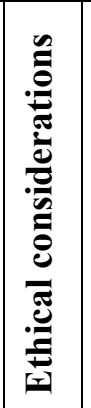 & 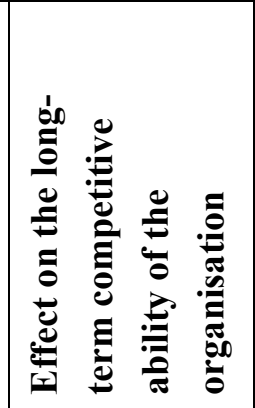 & 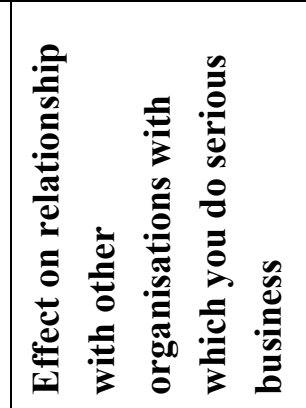 & 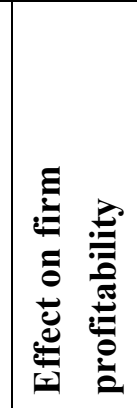 & 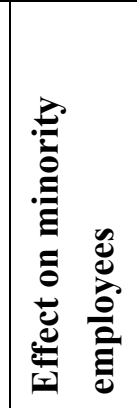 & 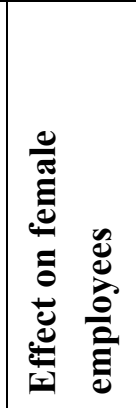 & 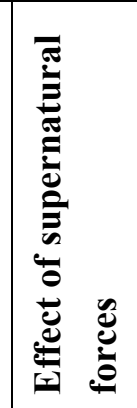 & 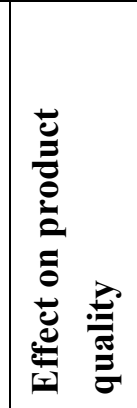 & 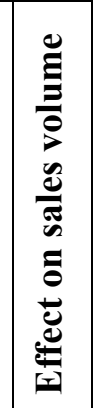 \\
\hline
\end{tabular}


The following outcomes constitute the most interesting results of the correlation analysis:

- Cost control and customer satisfaction are significantly positively correlated with the Performance Orientation dimension. Respondents who valued Performance Orientation rated the two decisional criteria with the highest importance.

- Employees' relations issues such as employees' well-being, safety, working conditions as well as the ethical considerations and effect of managerial decisions on minority employees are negatively linked to the Power Distance dimension.

- Contribution to the economic welfare of the nation as well as the welfare of the local community, together with effects of managerial decisions on the environment and female employees, are positively linked to the Humane Orientation dimension.

- Employees’ professional growth and development, effect on the long-term competitive ability of the organisation, effect on the relationship with other organisations with which firms do serious business, effect on firm profitability, together with the effect on product quality and effect on sales volume are all positively linked to the Performance Orientation dimension. On the other hand, the "effect of supernatural forces such as auspicious days, forecasts by fortune-tellers, and the like" is negatively linked to the respective cultural dimension.

- Cost control is strongest and positively linked to In-group Collectivism.

- Employees' professional growth and development is relatively strongly negatively correlated with Power Distance and positively correlated with Performance Orientation.

- Our "transcendental" criterion "pleasing, respecting, not offending a divine being, a god or an idol" is weakly but negatively correlated with Performance Orientation, however positively linked to the Uncertainty Avoidance dimension.

These results belong to the category of the correlations with the highest Pearson coefficient. However, our correlation analysis reveals much more interesting information on how the two concepts, namely the concept of culture and the concept of CSR are linked together in the minds of our respondents. Our main findings are discussed in the next chapter. 


\section{Discussion}

\section{Discussion on the profile of CSR-related criteria in managerial decision-making in the seven studied countries}

The analysis of the importance of CSR-related criteria in the decision-making process among business and engineering students in seven examined countries as a joint sample showed some interesting results and clear preferences. Outcomes of our study are useful for the conceptualisation of inter-country differences in regard to the CSR-related criteria from the viewpoint of university students, who are supposed to form the next managerial generation in companies worldwide. According to the given answers the observation can be made that students expressed highest importance to criteria that stand for long-term economic success of the organisations, i.e. customer satisfaction, product quality followed by profitability and long term competitiveness. At the same time the prospective decision-makers allocated less importance to such CSR-related criteria as ethical considerations, contributions to local community welfare, and economic welfare of the nation. Despite some inter-country differences, the list of the five most important CSR-related criteria in each country is rather similar. Could this result be considered as a clear indicator of cross-country convergence in preferences regarding the factors that have an impact on managerial decisionmaking?

In fact, very few studies have attempted to compare CSR-related issues and their changing pattern across countries and cultures. The situation is even more complicated if one considers the fact that the methodologies used in various studies on CSR differ substantially, thus the comparison between their results and ours is highly questionable. Moreover, our sample of respondents is rather special. Most of the CSR-oriented studies use managerial samples, not students, as it was done in our case. There are indications that the understanding of the CSR concept, and particularly the preferences related to CSR in the decisionmaking process, might differ substantially. For example, Catana and Catana (2010) discovered that at a first glance it seems that middle managers and students from Romania form a relative homogeneous population when it comes to ranking the importance of CSR preferences or decisions. On the other hand, a deeper analysis (with t-test on independent samples) showed statistically significant differences between the two groups' views on CSR for ten out of fifteen decisional criteria. The managerial population in Romania attached higher importance to the criteria of cost control, sales volume and long-term competitiveness. In turn, Romanian students expressed that higher importance should be given to the effect of managerial decisions on minority employees, on the environment and on economic welfare of the nation. Thus, according to Catana and Catana (2010: 26-27) „it seems that students tend to give a higher importance to ethical, environmental and quality of community and nation's life 
components of managerial decisions [...], while the managers stick with the economic 'zone' of social responsibility."

Further complications with the comparability of our results to other studies is linked with specifics of the Central and Eastern European countries, regarding their political, legislative and cultural background, which we have to consider while interpreting the results. However, some results of our research could be viewed within a broader context of inter-country differences in CSR. For example, Pinkston and Carroll (1994) studied differences in CSR-related issues among 131 natives of different countries working as managers in the US chemical industry. They found that natives of England, France, Germany, Japan, Sweden, Switzerland and the United States did not report significant differences in CSR orientation across countries. Non-significant results may have been due to the relatively small numbers of respondents per country. On the other hand, Burton, Farh and Hegarty (2000) examined the orientation toward CSR of 165 US and 157 Hong Kong business students. Although respondents from both countries viewed CSR as a construct in much the same way, many differences were found in the types of responsibilities considered most important. Specifically, Hong Kong students gave economic responsibilities more weight and non-economic responsibilities less weight than US students. Some authors indicate in their studies that respondents (as employees in a given company) in many countries perceive that their firms attach greater importance to shareholders or owners than employees nowadays, particularly in the transforming post-socialistic societies (Dryakhlov 2011).

Looking closer at the nation-wide context of CSR-related issues and their changing pattern within Europe itself, it is interesting to observe that for example Scandinavian countries and Sweden in particular, have a long history of research on integrating the economic issues with ethical and social responsibility issues into corporate strategies. Scandinavian companies have been exposed to strong environmental regulation since the 1980s. They not only explore CSR in academic research but also push CSR to be a "soft law" (May/Cheney/Poper 2007). Their democratic governments promote CSR development, constructing a reliable legal environment and tight collaboration with non-governmental organisations, which are encouraged to become more intense in the reflection of the CSR performance of the companies (Hawkins 2006). In other words, these countries know how to do business while taking human rights, anticorruption, and other ethical issues into account.

On the other hand CSR is still struggling to gain a foothold in Central and Eastern Europe. Although the concept of CSR is becoming increasingly popular in the CEE region, one of the main problems is that the wider public does not demand corporate responsibility to such an extent as people in developed countries do, so companies operating in the CEE region are not under the same pressure to behave ethically. Lewicka-Strzałecka (2006) claims that in countries 
with a developed market economy and a mature civic society the change of business strategies was enforced by pressure groups that demanded action for society and natural environment. In countries of transformation there is no or hardly any external pressure on companies to implement CSR. Serious obstacles are for example the negative image of business, dysfunctional legal background, corruption, and weakness of the non-governmental sector, a difficult economic situation of many companies, and a difficult situation on the labour market.

In the situation of a continuously changing legal environment and vigorous market competitiveness many small and medium sized companies often have to cope with financial problems. The main goal of the managers of these companies is maintaining financial solvency, therefore they do not concern themselves with long-term planning. Their everyday existence is dominated by struggling with bureaucracy, execution of financial assets from debtors or prolonging payments for creditors. A similar situation exists in most CEE countries.

All the factors outlined above could have an impact on the CSR development in the CEE countries. However, in this article we did not aim at differentiating between the practices related to CSR in various countries nor at comparing the evolution of the CSR concept in the "western" and "eastern" block. These issues might represent a substantial challenge for further investigation in the future, because there is a research gap in this particular field. Nevertheless, the primary aim of this article was to examine the overall profile of CSR-related criteria in managerial decision-making from the viewpoint of students from the respective seven countries. In this regard the research question we aimed to answer focused on the joint sample of our respondents from seven examined countries as a cluster.

\section{Discussion on the latent dimensions of CSR-related criteria in managerial decision- making}

Our study offers several interesting results that shed more light on CSR as a multidimensional phenomenon. Similarly to the Waldman et al. (2006) study we arrived at the conclusion that in the minds of our respondents CSR is a truly multidimensional construct. Waldman and colleagues in their article employed confirmatory factor analysis and discovered that their respondents, that is managers working mainly in higher executive positions, consider the CSR values closely connected with three different social groups or aspects, namely shareholders/owners social group, (other) stakeholders group, and the community/state welfare segment (Waldman et al. 2006: 833). However, our results offer some different conclusions, which may be caused by the differences in the two samples (students and managers) as well as the substantial differences between the European and US considerations regarding CSR. 
After conducting the factor analysis, we encountered some interesting outcomes. As indicated in the results section already, we discovered the CSR concept to be formed by four distinct factors, which were labelled as Profit, Longitudinality, Ethics and Common Good. This four-factor solution highlights the keystones of the CSR concept itself. Two factors, namely Longitudinality and Common Good pinpoint to the two fundamental aspects of the CSR concept: the first one highlights the long-term nature of the concept, whereas the second one stresses the perspective of "the other" as another essential feature of the CSR conception. The two other factors, Profit and Ethics stand for two pillars of the pyramid model of CSR (Carroll, 1991). They were differentiated in Carroll's model as the economic and ethical level of corporate responsibilities.

The economic responsibility implies an imperative "to gain profit!" and according to Carroll (1991: 226), it is the basic level of CSR. To be profitable is a necessity in order to be able to invest into CSR activities. So it is the basic prerequisite for socially responsible conduct of every organisation. The factor Profit, as indicated in our results, points to the interconnectedness of managerial CSR decisions with cost control, profitability of the firm as well as the volume of sales. From the stakeholders' perspective, Profit implies responsibility toward the shareholders/owners of an organisation.

The second level in Carroll's pyramid is the legal dimension of CSR. However, this type of corporate responsibilities was not espoused in our research, and we argue that the reason was that CSR-related criteria relating to the legal-bound responsibility were not included within the original GLOBE Student questionnaire, although the legal responsibility is an important constituent of the CSR concept. The principle "adhere to legal norms" (Carroll 1991: 227) defines evident boundaries of corporate conduct. Society requires first that companies have to stick with juridical norms. Unfortunately, from the ethical point of view, the legal system in a lot of societies is imperfect; when the corporation does not break any legal norm, it is not a guarantee that the firm acts ethically. Therefore, delineating ethical behaviour only with adherence to legal norms is a severe mistake. However, many entrepreneurs assume that if their organisations act in concordance with the law, and at the same time do not act in opposition to the law, there is no need to take the ethical perspective into account. Thus, it is a common error to interchange "ethical" with "legal".

The third, and perhaps the most important dimension of CSR in Carroll's model, is the ethical corporate responsibility. Contrary to the legal and economic levels, the adherence to the ethical level of CSR is hard to evaluate and measure. The basic imperative at the ethical level is to "act morally right!" toward every stakeholder (Carroll 1991: 228). It presupposes the commitment of the firm to act honestly and in a fair way to all parties (stakeholders) concerned. This dimension of CSR was again concluded in our research to be a distinct factor according to our respondents. Within the framework of our research, the factor 
Ethics entails managerial considerations regarding ethical issues, female employees and minorities working for the firm. The ethical level is considered as the heart of CSR, representing true moral imperatives of managers, which become important while making key decisions. From the stakeholders' perspective, Ethics implies responsibility toward specific employee groups, emphasising not only the wider ethical considerations but also the particular needs of certain employees, and thus respecting the individual within an organisation.

The third factor elicited in our research was the Common Good. It implies the wider circumstances in which every organisation operates and the overall social well-being. It encompasses the nation, the local community and the environment. These three decisional criteria represent three basic stakeholder groups within the cluster generally classified as the external stakeholders. Furthermore, from a philosophical standpoint it is assumed that taking care for the "others" presupposes a decline from individual needs and interests of the subject in order to be able to consider the external parties which are, to a various extent, influenced by the activities of the subject itself. From the stakeholders' perspective, the factor Common Good entails responsibility toward society, the community and the environment, supporting the global sustainability and social welfare for everyone. This factor stresses the responsibility of the company toward the whole society in which it operates as well as toward the future generations through preserving, or not harming, the environmental conditions.

Last but not least, the fourth factor, named Longitudinality, implies the future and long-term oriented perspectives which come into consideration when managers make their decisions. This factor covers decisional criteria like customer satisfaction, employees' relations, employees' growth, long-term competitiveness of the firm, relations with business partners and product quality. In fact, the long-term orientation is an inherent aspect of ethical reasoning. In managerial decision-making, when the manager finds him/herself in the situation of a moral dilemma, the ethical rationality and economic rationality are in irreconcilable contrast (Remišová 2011). Usually the ethical rationality of the decisional problem and ethical solution, which derives from this type of rationality, presumes a long-term orientation of the decisional subject. Generally, the solution of the dilemma which is ethically right encompasses the longitudinal aspect. And vice versa, the economic solution of a managerial moral dilemma does not have any longitudinal perspective. From the stakeholders' perspective, the factor Longitudinality entails responsibility for employees' work-related conditions as well as various types of business partners, thus implying that the firm should offer long-term oriented partnership with added value to employees and other business partners, like customers, competitors, etc. 
After conducting the correlation analysis between the four factors of the CSRrelated decisional criteria, results indicate that the factor of Profit is most strongly interconnected with the factor of Longitudinality. Future-oriented decisional criteria have a positive link with the profit-oriented ones, thus pointing to the importance of building long-term financial success on the grounds of customer satisfaction, product quality, employees' relations, employees' growth, long-term competitiveness of the firm, and affirmative relations with business partners. On the other hand, the factor Ethics is linked relatively strongly to Common Good, implying that emphasis on overall social well-being and welfare at national as well as community levels, together with caring for the environmental impacts of corporate actions is interconnected with the managerial considerations regarding specific ethical issues, like caring for female employees and minorities working for the organisation. Results show that the wider ethical concerns are bound to the specific ethical awareness, indicating that people who attach higher priorities to the internal ethical relations between employees will tend to put greater emphasis also on the externallyoriented ethical conduct of a corporation, which influences the society as a whole. Last but not least, the third important outcome of the correlation analysis reveals that long-term oriented business decisions are not only tight to the profit perspective, but also to external as well as ethical aspects of managerial decision-making. This pinpoints the awareness of future managers to the fact that without ethical conduct, which is responsible to employees as well as to external stakeholders, the business cannot operate successfully in the long run. Results of the correlation analysis in regard to the four factors of CSR-related decisional criteria underline the rational framework of managerial decisionmaking for cases where managers are facing a moral dilemma. Results confirm that the economic rationality does not have to be in opposition to the ethical rationality in decision-making. On the contrary, results indicate that the economic assumption of gaining profit can be in line with the ethical assumption of not harming anybody in business decisions. Building profitable businesses which are competitive in the long run have to be supported by ethically aware decisions.

Another interesting result regards the level of importance of the four decisional factors according to our future managers. On the basis of calculating mean scores for the four factors we concluded that the factor Profit seems to have the highest level of importance in the decision-making process, followed by Longitudinality and Common Good. The factor Ethics ranked as the least important one from the students' point of view. This result signifies the weight of profit as the basis for corporate survival. Without gaining profit, the organisation cannot fulfil other responsibilities. So, it is just logical that future managers attach the highest priority to profit-related decisions as their answers on the questionnaire items point to the fact that without gaining profit no company can survive in the market economy. However, in the contemporary 
globalized business environment there is an urgent need to consider with significance the ethical ways of reaching profit.

Nevertheless, according to our results, the Factor Ethics is left behind, becoming the least important perspective in the decision-making process. We believe that this result has to be seriously taken into account as the role of ethically-bound managerial optic should play a more important role in managerial decisionmaking. Furthermore we assume that the majority of our students had undergone formal education in business ethics. Still they do not apply equally high priority to the ethical perspective as to the profit itself. We think that there is an urgent need for today's business world to adhere more to the ethical regulation of the business environment. Although the factor Ethics scored 4.45 (mean value of importance on the 7-point scale), which indicates that ethical aspects are somehow important in managerial decisions (slightly above average level of importance), we suppose that there is still a large space for improvement in the sense of raising awareness of future managers to the moral rules of conducting business.

\section{Discussion on the interconnections between cultural dimensions and CSR-related criteria in managerial decision-making}

As already mentioned in the introductory part of this article, culture was researched on the basis of nine cultural dimensions. We took into consideration only the cultural values of the methodological design of the GLOBE Student project, which studied cultural practices and cultural values, the second representing the preferences of respondents in regard to certain cultural characteristics. In the CSR part of the GLOBE Student questionnaire the same logic was applied, studying the level of preferences in regard to seventeen criteria. First, the correlation analysis of the nine cultural dimensions and the four CSR-related decisional factors was conducted, and subsequently a correlation analysis of the nine cultural dimensions and seventeen single criteria was performed.

Results point out that there are many statistically significant links between the two studied phenomena. Cultural values are linked to single CSR-related decisional criteria, in some cases positively and in others negatively. Preferences for power distant and assertive behaviour are negatively connected with all four factors of CSR-related criteria. Both cultural dimensions imply rather rough, non-empathetic and directional behaviours, which are negatively linked to the CSR concept, it being an antipode to forceful and self-assertive tendencies in human manners.

The other seven dimensions of culture, i.e. Humane Orientation, Performance Orientation, Gender Egalitarianism, Collectivism (both In-group and Institutional), Future Orientation and Uncertainty Avoidance are positively linked to the CSR concept. The questionnaire used in this study asked 
respondents to assess the level of importance of certain criteria when making key managerial decisions. In reality the majority of key managerial decisions consider the performance issues of an organisation. Hence, it is logical that the preference for performance-related cultural values was positively correlated with the two factors that scored as the most important ones, namely Profit and Longitudinality.

Preferences of clear rules, non-ambivalent situations, certainty, and foreseeable consequences of actions and events were most strongly and positively linked to the factor Profit. Being able to control costs, volume of sales and overall profitability of a firm seems to reduce the fear of uncertainty. People who valued uncertainty avoidant conduct, attached the highest importance especially to the profit-oriented decisions.

Not surprisingly, the factor Institutional Collectivism was positively linked to the factor Common Good. There is a clearly positive interconnection between values of collective distribution of resources and collective action and managerial decisions concerning the social welfare of a nation, community, and the environmental influences of these decisions.

Preferences for In-group Collectivism, that is preferences for pride, loyalty and cohesiveness in the reference group, i.e. the family, work team or the whole organisation, were especially linked to Profit and Longitudinality. Hence, it can be concluded that loyalty and group cohesiveness values are built on the platform of three principles: firstly, being able to guarantee group members their personal development, good working conditions, and well-being, secondly offering a long-term partnership with added value toward all parties concerned, and thirdly with a guarantee of profitable solutions creating a secure and wealthy environment for the employees.

Another interesting outcome of the correlation analysis between the four factors of CSR-related criteria and the nine cultural dimensions regarded the Humane Orientation dimension. This represents preferences of people for being just, altruistic, welcoming, big-hearted, gentle and kind to others. These are all typical feminine values. These cultural values were especially linked to the factors of Common Good, Ethics and Longitudinality. Preferences for an equal, tolerant and empathetic environment are associated with the responsiveness for the national and community welfare, well-being of employee minorities and female employees as well as for the satisfaction of various business partners. Common Good, Ethics, and Longitudinality serve as the three most important keys to "the door of a feminine culture"; the first factor representing the care for others, the second the moral optic, and the third the long-term partnership with added value for everybody concerned.

After conducting the correlation analysis between the nine cultural dimensions and seventeen single decisional criteria, other interesting results were obtained. 
Again, the Power Distance and Assertive values were negatively linked with the majority of the CSR-related criteria. In regard to the Power Distance dimension, the only exception was the criterion labelled as the "effect of supernatural forces" with a positive connection. Forces like auspicious days, fortune-tellers, prophesiers and the like, in other words the force of the fate has an obviously positive link to the unequal distribution of power. Clearly, this result could be interpreted as the epitome of inequality, because the fate is all-mighty, at least for people with external locus of control (Rotter 1990). In regard to the Assertiveness dimension, the only positive link was the same as in the case of the Power Distance dimension.

Since from the statistical point of view significant links were found for 140 pairs of relations, from our evidence we picked out only the most interesting results; that is results with the strongest statistical support. For this interpretative part of our article we chose a different logic than used in the research results-related part; the results are interpreted from the respective cultural dimensions perspective.

Uncertainty Avoidance was positively linked to customer satisfaction. Hence, it can be concluded that loyalty of customers, and their tendency to come back which stems from their satisfaction could be a strong tool relieving the fear of uncertainty in the business environment. Next, the Future Orientation dimension was positively linked to the long-term competitive ability of an organisation and to the product quality, hence pointing to the importance of embracing the long run perspective into business decisions. Third, Power Distance together with Assertiveness were strongly negatively linked to employee relations issues like employees' well-being, work conditions and safety. Managers who tend to value a self-assertive, authoritarian and power distant style of communication would probably attach less importance to employee issues. Not surprisingly, Institutional Collectivism was positively linked to a criterion labelled as the contribution to the welfare of a nation. Another cultural dimension, In-group Collectivism, was positively linked especially to cost control, this result being the most puzzling one. Nevertheless, if we take into consideration that In-group Collectivism might point among other cultural features also to the fact that individual goals have to be less prioritised in favour of group goals, then the interpretation of this result might be less problematic. If a group wishes to endure, the profit, in its various forms, has to be gained. Hence in order to be profitable, cost control is one of the tools aiming at raising the profits.

\section{Conclusion}

Our research findings have some limitations. Perhaps the most serious one relates to the nature of our sample. We are aware that assuming that business and engineering students will be a core part of the future managers' population is risky. It should be taken into account that their preferences in regard to the 
CSR-related criteria in decision-making might change in the processes of socialisation into organisational structures and cultures after graduating from universities, so we cannot be sure, whether the present students' opinions would illustrate the future managers' ones. Furthermore, our comparisons with other research findings, which other researchers produced based on different research instruments, samples and in different periods might be problematic, too. In spite of these limitations, we still believe that our research findings offer certain insights into the relevant issues.

Carroll, as one of the dominant authorities in the contemporary CSR debate once stated that „social responsibility can only become reality if more managers become moral instead of amoral or immoral“ (Carroll 1991: 225). We believe that his declaration embraces the mission of our research. We assume that the decisions of managerial personnel are equally important for the CSR development as the strategy, and processes. Managers influence other people and subsequently, the course of action of the whole organisation through their decisions in common as well as critical situations. As the managers are the dominant creators of the character of organisational culture, their value system is one of the determinants of adherence to responsibility principles within every organisation. Therefore higher emphasis should be laid on the key actors in the corporate world - the managers, and the moral standards of their decisions regarding corporate actions.

Outcomes addressed in this article are significant also for the scientific discipline of business ethics, because they elicit issues, which are underresearched. The individual decision-making process that relates to the sphere of moral reasoning, which is the case of CSR-related decision-making, lacks support of systematic empirical evidence. Moreover, the research of intercultural differences and their impact on moral reasoning is substantially marginalized, thus creating a substantial knowledge niche. In the mirror of these facts, this article aspires to fill this research gap, at least partially.

Results of our study reveal new knowledge concerning the culture-CSR links. If we consider the cultural values researched in this study, there is a number of significant links between the culturally-bound preferences of people and their preferences in regard to the CSR-related criteria of managerial decision-making. On the other hand, we also have to consider the overall scope of the GLOBE Student project, on the basis of which the cultural values were assessed. Nine cultural dimensions are in the contemporary intercultural management debate the broadest framework operating within the dimension-oriented paradigm: Hofstede, for example, uses five dimensions (Hofstede/Hofstede 2005) and Trompenaars applies seven dimensions of intercultural differences (Trompenaars/Hampden-Turner 1998). However, other approaches to the systemisation of intercultural differences across the globe (see for example Gannon 2009; Thomas 1996) indicate other distinctions between cultures, which 
are not covered by the dimension-oriented paradigm. Thus, in the conceptualisation of culture-CSR interconnections, some important culturerelated knowledge might be missing. Yet, the GLOBE Student approach to the research of intercultural differences on the basis of cultural dimensions offers, as the authors of this article assume, sufficient foundation for an illumination of the links between the concept of culture and the concept of CSR.

Due to the complex nature of the culture-CSR linkage, this article cannot encompass all aspects of the studied phenomena. Future research should focus on in-depth studies dealing with the multifaceted issue of whether the concept of CSR, particularly the CSR-related managerial decision-making process, is culturally endorsed. Links between ethical leadership, which constitutes one pillar of practical realisation of the CSR concept, and culture should be précised, too. The systematic verification of cultural as well as non-cultural predictors of the CSR-related decision-making has to be researched in order to expand a comprehensive understanding on the topic.

\section{References}

Ben, S./Bolton, D. (2011): Corporate social responsibility. London: Sage.

Búciová, Z. (2009): O zmenách v chápaní spoločenskej zodpovednosti podnikov, in: Kdo je aktérem společenské odpovědnosti firem? Olomouc: MVSO, 21-32.

Burton, B./Farh, J.L./Hegarty, H. (2000): A cross-cultural comparison of corporate social responsibility orientation: Hong Kong vs. US students, in: Teaching Business Ethics 4: Kluwer Academic Publishers, 151-167.

Buysee, K./Verbeke, A. (2003): Proactive environmental strategies: A stakeholder management perspective, in: Strategic Management Journal, 24, 453-470.

Carroll, A.B. (1979): A three-dimensional conceptual model of corporate performance, in: Academy of Management Review, 4, 4, 497-505.

Carroll, A.B. (1991): The pyramid of corporate social responsibility: Toward the moral management of organizational stakeholders, in: Business Horizons, July-August, 39-48.

Catana, D./Catana, Gh. A. (2010): Social responsibility values: Managers and students perspective, in: Proceedings, International Conference on Marketing, $3^{\text {rd }}$ edition, Marketing from Information to Decision, Cluj-Napoca, October 29-30, 19-29.

Crane, A./Matten, D. (2004): Business ethics. New York: Oxford University Press.

Dahlsrut, A. (2006): How corporate social responsibility is defined: An analysis of 37 definitions, in: Corporate Social Responsibility and Environmental Management. Published online in Wiley InterScience, available at http://www.mcxindia.com/csr/newsarticle/pdf/csr_news45.pdf

Dryakhlov, N.I. (ed.) (2011): Corporate culture: Problems and tendencies of development in the world and in Russia. Moscow: Nauka.

Freeman, R.E. (1984): Strategic management: A stakeholder approach. Marshfield: Pittman.

Gannon, M.J. (2009): Understanding global cultures. Thousand Oaks: Sage. 
Garriga, E./Melé, D. (2004): Corporate social responsibility theories: Mapping the territory, in: Journal of Business Ethics, 53, 51-71.

Hawkins, D.E. (2006): Corporate social responsibility: Balancing tomorrow's sustainability and today's profitability. New York: Palgrave Macmillan.

Hofstede, G./Hofstede, G.J. (2005): Cultures and organizations: Software of the mind. New York: McGraw-Hill.

Lewicka-Strzałecka, A. (2006): Opportunities and limitations of CSR in the post communist countries: Polish case, in: Corporate Governance, Bradford, 6, 4, 440-448.

Maignan, I./Ralston, D.A. (2002): Corporate social responsibility in Europe and the U.S.: Insights from businesses' self-presentations, in: Journal of International Business Studies, 33, 3, 497514.

Matten D./Moon, J. (2008): “Implicit” and "explicit” CSR: A conceptual framework for a comparative understanding of corporate social responsibility, in: Academy of Management Review, 33, 2, 404-424.

May, S./Cheney, G./Poper, J. (2007): The debate over corporate social responsibility. New York: Oxford University Press.

Melé, D. (2008): Corporate social responsibility theories, in: Crane, A./McWilliams, A./Matten, D./Moon, J./Siegel, D.S. (eds.): The Oxford handbook of corporate social responsibility. New York: Oxford University Press, 47-81.

Pinkston, T.S./Carroll A.B. (1994): Corporate citizenship perspective and foreign direct investment in the U.S., in: Journal of Business Ethics 13, 157-169.

Remišová, A. (2011): Etika a ekonomika. Bratislava: Kalligram.

Remišová, A./Búciová, Z. (2012): Measuring corporate social responsibility towards employees, in: Journal for East European Management Studies, 17, 3, 273-291.

Rotter, J.B. (1990): Internal versus external control of reinforcement, in: American Psychologist, 45, 4, 489-493.

Schwartz, S. (1994): Are there universal aspects in the structure and contents of human values?, in: Journal of Social Issues, 50, 4, 19-45.

Schwartz, S. (2007): Value orientations: Measurement, antecedents and consequences across nations, in: Jowell, R./Roberts, C./Fitzgerald, R./Eva, G. (eds.): Measuring attitudes cross-nationally: Lessons from the European social survey. London: Sage, 169-203.

Schwartz, S./Melech, G./Lehmann, A./Burgess, S./Harris, M./Owens, V. (2001): Extending the crosscultural validity of the theory of basic human values with a different method of measurement, in: Journal of Cross-Cultural Psychology, 32, 5, 519-542.

Thomas, A. (ed.) (1996): Psychologie interkulturellen Handelns. Göttingen: Hogrefe.

Trompenaars, F./Hampden-Turner, Ch. (1998): Riding the waves of culture: Understanding diversity in global business. New York: McGraw-Hill.

Waldman, D.A./Sully de Luque, M./Washburn, N./House, R.J./et al. (2006): Cultural and leadership predictors of corporate social responsibility values of top management: A GLOBE study of 15 countries, in: Journal of International Business Studies, 37, 823-837. 